\title{
Pomological traits, phenol and flavonoid content and antioxidant activity introduced the pomegranate (Punica granatum L.) cultivars grown in the Mediterranean part of Croatia
}

\author{
Pomološka svojstava, sadržaj fenola i flavonoida te antioksidativna \\ aktivnost introduciranih sorata šipka (Punica granatum L.) \\ uzgajanih u mediteranskom dijelu Republike Hrvatske
}

\author{
Mira Radunić, Jelena Gadže, Katarina Lozo, Ela Šimera, \\ Maja Jukić Špika
}

\begin{abstract}
Fruit samples of 'Granada', 'Wonderful' and 'Hicaznar' cultivars were collected in productive pomegranate orchard in Neretva valley, Metković (Croatia) and their pomological and chemical properties were compared. Significant differences among cultivars were noted between the studied traits. Fruit weight ranged from $429.37 \mathrm{~g}$ to $359.43 \mathrm{~g}$ and the lowest was recorded in cv. 'Hicaznar'. Color of peel, aril and juice of all investigated cultivars was intensively red and dark red, respectively. 'Granada' and 'Wonderful' stood out with high juice yield compared with 'Hicaznar'. Total soluble solid (TSS) of 'Hicaznar' (18.61\%) was higher than that of 'Wonderful' (16.64\%). Total acidity (TA) significantly differed among cultivars and ranged from $1.6 \%$ to $2.1 \%$. According to the TSS/TA ratio investigated cultivars belong to the group of soursweet cultivars. Dissimilarity between cultivars was found in the phenolics content (TPC). It ranged from 679.6 to $906.6 \mathrm{mg} / 100 \mathrm{~g} \mathrm{D.W}$. where 'Hicaznar' stood out as a cultivar with highest TPC and also highest flavonoid and non-flavonoid content (521.1 $\mathrm{mg} / 100 \mathrm{~g} \mathrm{D}$.W. and $385.5 \mathrm{mg} / 100 \mathrm{~g}$ D.W., respectively). In 'Granada' antioxidant activity measured by 1,1-diphenyl-2-picrylhydrazyl was recorded for $64.1 \%$, in 'Wonderful' $70.2 \%$ and the highest in 'Hicaznar' (74.5\%). Results of this assessment are the basis for practical determination of the pomegranate use.
\end{abstract}

Keywords: pomological properties, quality, phenolic, total anthocyanin content, cultivars 
M. Radunić et al.: Pomological traits, phenol and flavonoid content and antioxidant activity introduced tje pomegranate (Punica granatum L.) cultivars grown in the

\section{SAŽETAK}

Uzorci plodova sorata 'Granada', 'Wonderful' i 'Hicaznar' prikupljeni su u proizvodnom nasadu šipka u dolini rijeke Neretve, Metković (Hrvatska) te su uspoređene njihove pomološke i kemijske karakteristike. Između istraživanih sorata utvrđene su značajne razlike. Masa ploda varirala je od 429,37 g do 359,43 g, a najmanja masa ploda utvrđena je kod sorte 'Hicaznar'. Boja kore i arilusa (zrna) te soka svih istraživanih sorata je crvena odnosno tamno crvena. Plodovi sorte 'Granada' i 'Wonderful' istaknuli su se višim randmanom soka u usporedbi sa sortom 'Hicaznar'. Sadržaj topljive suhe tvari (TSS) sorte 'Hicaznar' $(18,61 \%)$ je veći u odnosu na TSS sorte 'Wonderful' (16,64\%). Ukupna kiselost (TA) se značajno razlikovala između sorata i varirala je od $1,6 \%$ do $2,1 \%$. Temeljem TSS/TA odnosa istraživane sorte pripadaju skupini kiselo-slatkih sorata. Različitost između sorata utvrđena je u sadržaju fenolnih spojeva (TPC) koji su bili u rasponu od 679,6 do 906,6 mg/100 g s.tv. Sorta 'Hicaznar' se istakla najvećim sadržajem ukupnih fenola, kao i sadržajem flavonoida i ne-flavonoida $(521,1 \mathrm{mg} / 100 \mathrm{~g}$ s.tv. i $385,5 \mathrm{mg} / 100 \mathrm{~g}$ s.tv.). Antioksidacijska aktivnost mjerena sa 1,1-diphenyl-2-picrylhydrazyl sorte 'Granada' iznosila je 64,1\%, 'Wonderful' 70,2\%, a najveća je bila kod sorte 'Hicaznar' (74.5\%). Rezultati ovog istraživanja osnova su za definiranje mogućnosti uporabe šipka.

Ključne riječi: pomološka svojstva, kakvoća, fenoli, sadržaj ukupnih antocijana, sorta

\section{INTRODUCTION}

Extensive knowledge of pomegranate's health attributes, due to high levels of antioxidant compounds contained that protecting against harmful free radicals, advance pomegranates consumption and therefore also its production. Genotype, growing region, climate, maturity and cultural practices are main variables that affects quality of pomegranate fruit and a number of studies have been carried out in different pomegranate producing regions (Gil et al, 2000.; Durgac et al, 2008.; Al-Said et al, 2009.; Cristofori et al, 2010.; Tehranifar et al, 2010.; Martinez et al, 2012.; Radunić et al, 2015.).

One of the traditional fruits cultivated in the Mediterranean part of Croatia is a pomegranate (Punica granatum L.). As in other countries, that have Mediterranean-like climate suggested as optimal for pomegranate fruit growth (Schwartz et al., 2009), there is a growing interest in planting new orchards. In new orchards in Croatia alongside domestic cultivars in recent years also foreign cultivars have been planted. As new cultivars merge in commercial 
M. Radunić et al.: Pomological traits, phenol and flavonoid content and antioxidant activity introduced tje pomegranate (Punica granatum L.) cultivars grown in the Mediterranean part of Croatia

farming, it is expedient to investigate the quality potential of newly introduced cultivars.

The aim of this study was to compare and characterize pomegranate cultivars 'Granada', 'Wonderful' and 'Hicaznar' in the agro-ecological conditions of the Neretva valley (Croatia). Pomological (fruit weight, peel color and thickness, number of arils, color, weight and yield of arils, seed yield, juice yield and color) as well as chemical (total soluble solids, total acidity, TSS/TA, total phenol, flavonoid and non-flavonoid content, total anthocyanin content, antioxidant activity) properties were determined.

\section{MATERIALS AND METHODS}

Fruit samples of three pomegranate cultivars ('Granada', 'Wonderful' and 'Hicaznar') were collected from an orchard in Metković, Croatia in the year 2016. Trees were trained to form a bush, with three to four main trunks and planted at a spacing of $3 \times 4.5 \mathrm{~m}$. For each cultivar, nine fruit of uniform size were randomly collected from around the canopy ( 3 fruit per tree $\mathrm{x} 3$ trees).

Fruit weight ( $\mathrm{g}$ ) was determined using a digital balance (Mettler Toledo AB 204, Swizeland; $\pm 0.01 \mathrm{~g}$ sensitivity), Peel thickness was determined using digital caliper; two measurements were recorded from opposite sides of the fruit. Arils were manually separated from the pericarp/membrane and total aril weight per fruit was recorded. Number of arils per fruit was estimated by counting the number of arils in a $100 \mathrm{~g}$ sample extrapolating the number of arils based on the total arils weight per fruit. Aril color was determined based on the coloration scale from cream to dark red (cream, light pink, pink, red, dark red). Aril yield (\%) was determined as the ratio between aril weight and fruit weight, multiplied by 100 . Juice was obtained from a $50 \mathrm{~g}$ of arils by pressing through four layers of cheesecloth and juice yield (\%) was determined as the ratio between acquired milliliters of juice per $50 \mathrm{~g}$ sample, multiplied by 100 . Seed yield (\%) was determined as the ratio between seeds weight and arils weight per fruit, multipled by 100 .

Fresh aril juice extracted after pressing through cheesecloth as previously described was used for measuring of total soluble solids, total acidity and TSS/TA ratio. Total soluble solids (TSS) was determined using an Abbe refractometer (A. Kruss Optronic, Germany), with results expressed as percentage (at $20^{\circ} \mathrm{C}$ ). According to the AOAC method (1995), total acidity (TA) was measured and expressed as percentage of citric acid equivalents. The above values were used to calculate the TSS/TA ratio. 
M. Radunić et al.: Pomological traits, phenol and flavonoid content and antioxidant activity introduced tje pomegranate (Punica granatum L.) cultivars grown in the Mediterranean part of Croatia

Extract was performed for analyses of phenolic, non-flavonoid, flavonoid content and DPPH assay. A sample of freeze-dried pomegranate arils (dried using a FreeZone 2.5 Liter Benchtop Freeze Dryer, LabConco, USA) were grinded in a stainless steel mill (A 11 Analytical mill, IKA). Powdered tissue $(0.5 \mathrm{~g})$ was vortexed (Biosan, V1 plus, Latvia) for $1 \mathrm{~min}$ with $10 \mathrm{~mL}$ of $80 \%$ aqueous methanol and extracted in ultrasonic bath (Sonorex Digitec DT 100H, Bandelin) for $15 \mathrm{~min}$. The extract was centrifuged (Beckman Instruments J2-21, Palo Alto, CA) at $5.000 \mathrm{rpm}$ for $25 \mathrm{~min}$. Total phenolic content was determined using the colorimetric Folin-Ciocalteu method (Singleton and Rossi, 1965.). Results were expressed as $\mathrm{mg} / 100 \mathrm{~g}$ D.W. To determine non-flavonoid and flavonoid content the method by Kramling and Singleton (1969) was used. The concentration of non-flavonoid content was calculated as the concentration of total phenolic content, while the concentration of the flavonoid content was calculated from the differences between total phenols and non-flavonoids. According to Brand-Williams et al. (1995) antioxidant activity was determinated using 1.1-diphenyl-2-picrylhydrazyl reagent and the total anthocyanin content using bisulphite bleaching method (Ribéreau-Gayon and Stonestreet, 1965). The molar absorbance value for cyanidin-3.5-diglucoside was used as a standard value and results were expressed as mg cyanidin-3.5diglucoside equivalents $/ 100 \mathrm{~g} \mathrm{D.W}$.

Data obtained from this study were analyzed using Statistica software version 11.0 (StatSoft, Inc.USA, 2012). To determine the difference among cultivars in pomological and chemical fruit properties analysis of variance (ANOVA) was performed. Differences among means were considered significant at $\mathrm{p} \leq 0.05$ using Tukey's Honest Significant Difference test.

\section{RESULTS AND DISCUSSION}

Results of fruit, arils and seed analyses of 'Granada', 'Wonderful' and 'Hicaznar' cultivars are presented in Table 1. 'Granada' and 'Wonderful' had a significantly higher fruit weight (399.34 $\mathrm{g}$ and $429.37 \mathrm{~g}$, respectively) than 'Hicaznar' (359.43g). All of the examined cultivars can be described as intensive red peel cultivars. Peel thickness significantly differed between cultivars ranging from 4.8 to $5.4 \mathrm{~mm}$, where 'Hicaznar' had the lowest value. Preference for fresh consumption in general is pomegranate fruit of red color and thin peel. Intensive color for consumers is more attractive and they link the color with fresher and better taste while thin peel cultivars are preferred because of easier cleaning. The number of arils per fruit varied between 1238 
M. Radunić et al.: Pomological traits, phenol and flavonoid content and antioxidant activity introduced tje pomegranate (Punica granatum L.) cultivars grown in the

Mediterranean part of Croatia

and 1331 (Table 1) which is higher than number of arils per fruit of domestic cultivars 'Sladun' and 'Barski slatki' (data not shown). Since each aril derives from a successfully fertilized ovule, higher number of arils per fruit is the indication of successful fertilization (Wetzstein, et al., 2011.).

Table 1 Fruit, aril and seed properties of introduced pomegranate cultivars grown in Mediterranean part of Croatia

Tablica 1. Karakteristike ploda, arilusa i sjemenke introduciranih sorata šipka uzgajanih u mediteranskom dijelu Republike Hrvatske

\begin{tabular}{|l|c|c|c|}
\hline & \multicolumn{3}{|c|}{ Cultivar /Sorta } \\
\hline & Granada & Wonderful & Hicazar \\
\hline $\begin{array}{l}\text { Fruit weight (g) } \\
\text { Masa ploda (g) }\end{array}$ & $399.34 \mathrm{a}$ & $429.37 \mathrm{a}$ & $359.43 \mathrm{~b}$ \\
\hline $\begin{array}{l}\text { Peel color } \\
\text { Boja kore }\end{array}$ & $\begin{array}{c}\text { red } \\
\text { crvena }\end{array}$ & $\begin{array}{c}\text { red } \\
\text { crvena }\end{array}$ & $\begin{array}{c}\text { red } \\
\text { crvena }\end{array}$ \\
\hline $\begin{array}{l}\text { Peel thickness (mm) } \\
\text { Debljina kore (mm) }\end{array}$ & $5.2 \mathrm{a}$ & $5.4 \mathrm{a}$ & $4.8 \mathrm{~b}$ \\
\hline $\begin{array}{l}\text { Number of arils } \\
\text { Broj arilusa }\end{array}$ & $1238 \mathrm{a}$ & $1331 \mathrm{a}$ & $1258 \mathrm{a}$ \\
\hline $\begin{array}{l}\text { Aril color } \\
\text { Boja arilusa }\end{array}$ & dark red & dark red & dark red \\
\hline $\begin{array}{l}\text { Aril weight (g) } \\
\text { Masa arilusa (g) }\end{array}$ & $0.34 \mathrm{a}$ & $0.33 \mathrm{a}$ & $0.29 \mathrm{a}$ \\
\hline $\begin{array}{l}\text { Aril yield (\%) } \\
\text { Randman arilusa (\%) }\end{array}$ & $44 \mathrm{ab}$ & $43.6 \mathrm{~b}$ & $51.6 \mathrm{a}$ \\
\hline $\begin{array}{l}\text { Seed yield (\%) } \\
\text { Randman sjemenke (\%) }\end{array}$ & $7.23 \mathrm{a}$ & $6.47 \mathrm{a}$ & $6.09 \mathrm{a}$ \\
\hline
\end{tabular}

Mean values $(\mathrm{n}=9)$ followed by different lower-case letters in each row indicate significant differences at $\mathrm{p} \leq$ 0.05 .

Srednje vrijednosti $(n=9)$ označene različitim slovima unutar reda označavaju statistički značajne razlike za $p$ $\leq 0,05$.

Differences in aril color among investigated cultivars were not found and a characteristic of all cultivars is the dark red color of arils (Table 1). In a study conducted by Celik and Ercisli (2009.) investigating physical properties of pomegranate cv. 'Eksinar' red aril color was emphased as one of the most important sensory characteristics of pomegranate pulp and juice. Likewise, the attractive aril pigment, as mentioned above for peel color, may be an important factor for consumers' acceptance and purchase increase when a pomegranate is peeled or when consumers are already familiar with the cultivar characteristics. Difference between cultivars in aril weight was not found. In contrast, 
M. Radunić et al.: Pomological traits, phenol and flavonoid content and antioxidant activity introduced tje pomegranate (Punica granatum L.) cultivars grown in the

Mediterranean part of Croatia

significant variability in aril weight was observed in literature (Martinez et al, 2006.; Tehranifar et al, 2010.; Martinez et al, 2012.). Aril yield (as a percentage of total fruit weight) ranged from $43.6 \%$ to $51.6 \%$. These results are in agreements with investigation on pomegranates conducted in Turkey (36.959.4\%) (Durgac et al, 2008.), Italy (44.5-53.5\%) (Cristofori et al, 2010.), Iran (41.1-65.0\%) (Tehranifar et al, 2010.), and Morocco (53.4-61.2\%) (Martinez et al, 2012.).

Properties of the investigated cultivar juices are depicted in Table 2. Different juice yield was found between studied pomegranate cultivars. 'Granada' and 'Wonderful' (65.4\% and 66.0\%, respectively) had higher juice yield than 'Hicaznar' (54.7\%). Optimal maturity for harvesting is achieved through balance of main attributes such as fruit size, peel color and sugar content. In present study, cultivar significantly influenced total soluble solids (TSS) and total acidity (TA) content. The TSS ranged from $16.64 \%$ ('Wonderful') to $18.61 \%$ ('Hicaznar') and the TA from $1.62 \%$ ('Wonderful') to $2.08 \%$ ('Hicaznar'). The ratio of the two just listed parameters is an important quality factor. Though dissimilarities were found between single parameter in studied cultivars, difference in TSS/TA was not found. The TSS/TA ratio is considered a better indicator of taste for most fruit species than individual sugar content (in present study as TSS) or acids. Each pomegranate cultivar requires a certain TSS/TA ratio at harvest time. Consequently, classifications by Onur and Kaska (1985) and Martinez et al. (2006) define cultivars 'Granada', 'Wonderful' and 'Hicaznar' as sour-sweet cultivars.

Sensory attributes of fruits and vegetables are linked with phenolic compounds (Gil et al, 2000.). Total phenol, flavonoid and non-flavanoid content of tree introduced pomegranate cultivars grown in the Mediterranean part of Croatia is presented in Table 2. Phenolic compounds content ranged from 679.6 to $906.6 \mathrm{mg} / 100 \mathrm{~g}$ D.W. where 'Hicaznar' stands out as a cultivar with the highest TPC and also flavonoid and non-flavonoid content. Pomegranate has high antioxidant activity, primarily attributed to its high phenols content. Furthermore, it is an important source of anthocyanins, which are wholly responsible for red aril color (Gil et al, 2000.; Aviram et al, 2008.; Radunić et al, 2015.). In our study, the dissimilarity between cultivars was found in the anthocyanins content. 'Granada' and 'Hicaznar' had higher total anthocyanins content than 'Wonderful'. The highest antioxidant capacity according to DPPH method was recorded in 'Hicaznar'. The results are most likely related to the amount of phenolics since antioxidant activity (DPPH) was highly correlated with TPC $(r=0.820)$ (Radunić et al, 2015.). 
M. Radunić et al.: Pomological traits, phenol and flavonoid content and antioxidant activity introduced tje pomegranate (Punica granatum L.) cultivars grown in the

Mediterranean part of Croatia

Table 2 Juice properties of introduced pomegranate cultivars grown in Mediterranean part of Croatia

Tablica 2. Karakteristike soka introduciranih sorata šipka uzgajanih u mediteranskom dijelu Republike Hrvatske

\begin{tabular}{|c|c|c|c|}
\hline & \multicolumn{3}{|c|}{ Cultivar /Sorta } \\
\hline & Granada & Wonderful & Hicazar \\
\hline $\begin{array}{l}\text { Juice yield (\%) } \\
\text { Randman soka (\%) }\end{array}$ & $65.4 \mathrm{a}$ & $66.0 \mathrm{a}$ & $54.7 \mathrm{~b}$ \\
\hline $\begin{array}{l}\text { Juice color } \\
\text { Boja soka }\end{array}$ & $\begin{array}{c}\text { dark red } \\
\text { tamno crvena }\end{array}$ & $\begin{array}{c}\text { dark red } \\
\text { tamno crvena }\end{array}$ & $\begin{array}{c}\text { dark red } \\
\text { tamno crvena }\end{array}$ \\
\hline $\begin{array}{l}\text { Total soluble solid } \\
\text { (TSS; }{ }^{\circ} \text { Brix) } \\
\text { Suha tvar }\left({ }^{\circ} \text { Brix }\right)\end{array}$ & $17.35 \mathrm{ab}$ & $16.64 \mathrm{~b}$ & $18.61 \mathrm{a}$ \\
\hline $\begin{array}{l}\text { Total acidity (\%) } \\
\text { Ukupne kiseline (\%) }\end{array}$ & $1.85 \mathrm{~b}$ & $1.62 \mathrm{c}$ & $2.08 \mathrm{a}$ \\
\hline TSS/TA & $9.91 \mathrm{a}$ & $10.49 \mathrm{a}$ & $9.23 \mathrm{a}$ \\
\hline $\begin{array}{l}\text { Taste } \\
\text { Okus }\end{array}$ & $\begin{array}{c}\text { sour-sweet } \\
\text { kiselo-sladak }\end{array}$ & $\begin{array}{c}\text { sour-sweet } \\
\text { kiselo-sladak }\end{array}$ & $\begin{array}{c}\text { sour-sweet } \\
\text { kiselo-sladak }\end{array}$ \\
\hline $\begin{array}{l}\text { Total phenol content } \\
\text { (mg/100g D.W.) } \\
\text { Ukupni fenoli } \\
\text { (mg/100g s.tv.) }\end{array}$ & $679.6 \mathrm{~b}$ & $696.5 \mathrm{~b}$ & $906.6 \mathrm{a}$ \\
\hline $\begin{array}{l}\text { Flavonoid content } \\
\text { (mg/100g D.W.) } \\
\text { Sadržaj flavonoida } \\
\text { (mg/100g s.tv.) }\end{array}$ & $393.6 \mathrm{~b}$ & $447.2 \mathrm{~b}$ & $521.1 \mathrm{a}$ \\
\hline $\begin{array}{l}\text { Non-flavonoid content } \\
\text { (mg/100g D.W.) } \\
\text { Sadržaj ne-flavonoida } \\
\text { (mg/100g s.tv.) }\end{array}$ & $286.1 \mathrm{~b}$ & $249.40 \mathrm{~b}$ & $385.5 \mathrm{a}$ \\
\hline $\begin{array}{l}\text { Total anthocyanins } \\
\text { content (mg/100g D.W.) } \\
\text { Ukupni antocijani } \\
\text { (mg/100g s.tv.) }\end{array}$ & $81.06 \mathrm{a}$ & $66.7 \mathrm{~b}$ & 86.29 a \\
\hline DPPH (\%) & $64.1 \mathrm{c}$ & $70.2 \mathrm{~b}$ & $74.5 \mathrm{a}$ \\
\hline
\end{tabular}

Mean values $(\mathrm{n}=9)$ followed by different lower-case letters in each row indicate significant differences at $\mathrm{p} \leq$ 0.05 .

Srednje vrijednosti $(n=9)$ označene različitim slovima unutar reda označavaju statistički značajne razlike za $p$ $\leq 0,05$. 
M. Radunić et al.: Pomological traits, phenol and flavonoid content and antioxidant activity introduced tje pomegranate (Punica granatum L.) cultivars grown in the

Mediterranean part of Croatia

We have characterized and compared for the first time the pomological and chemical attributes of foreign pomegranate cultivars grown in Croatia. 'Granada', 'Wonderful' and 'Hicaznar' belong to the sour-sweet cultivars with high bioactive components adequate for fresh consumption but also for processing.

\section{REFERENCES}

AL-SAID, F. A., OPARA, L. U., AL-YAHYAI, R. A. (2009): Physicochemical and textural quality attributes of pomegranate cultivars (Punica granatum L.) grown in the Sultanate of Oman. Journal of Food Enginering. 90:129-134.

AOAC (1995). Official methods of analysis (16th ed.). Washington, DC: Association of Official Analytical Chemists.

AVIRAM, M., VOLKOVA, N., COLEMAN, R., DREHER, M., REDDY, M. K., FERREIRA, D. (2008): Pomegranate phenolic from the peels, arils, and flowers are antiatherogenic: Studies in vivo in atherosclerotic apolipoprotein e-deficient (E 0) mice and in vitro in cultured macrophages and lipoproteins. Journal of Agriculture and Food Chemistry. 56: 1148-1157.

BRAND-WILLIAMS, W., CUVELIER, M. E., BERSET, C. (1995): Use of a free radical method to evaluate antioxidant activity. LWT - Food Science and Technology. 28: 25-30.

CELIK, A., ERCISLI, S. (2009): Some physical properties of pomegranate cv. Eksinar. International Agrophysics. 23: 295-298.

CRISTOFORI, V., CARUSO, D., LATINI, G., DELL'AGLI, M., CAMMILLI, C., RUGINI, E. (2010): Fruit quality of Italian pomegranate (Punica granatum L.) autochthonous varieties. European Food Research and Technology. 232(1): 397-403.

DURGAC, C., OZGEN, M., SIMSEK, O., KACAR, Y. K., KIYGAL, Y., CELEBI, S. (2008): Molecular and pomological diversity among pomegranate (Punica granatum L.) cultivars in Eastern Mediterranean region of Turkey. African Journal of Biotechnology. 7(9): 1294-1301. 
M. Radunić et al.: Pomological traits, phenol and flavonoid content and antioxidant activity introduced tje pomegranate (Punica granatum L.) cultivars grown in the

GIL, M. I., TOMAS-BERBERAN, A., HESS-PIERCE, B., HOLCROFT, D. M., KADER, A. A. (2000): Antioxidant activity of pomegranate juice and its relationship with phenolic composition and processing. Journal of Agriculture and Food Chemistry. 48: 4581-4589.

KRAMLING T.E., AND SINGLETON V.L (1969): An estimate of the nonflavonoid phenols in wines. American Journal of Enology and Viticulture. 20: 86-92.

MARTINEZ, J. J., MELGAREJO, P., HERNANDEZ, F., SALAZARM, D. M., MARTINEZ, R. (2006:). Seed characterization of five new pomegranate (Punica granatum L.) varieties. Scientia Horticulturae. 110: 241-246.

MARTINEZ, J. J., HERNANDEZ, F., ABDELMAJID, H., LEGUA, P., MARTINEZ, R., AMINE, A. E., (2012): Physico-chemical characterization of six pomegranate cultivars from Morocco: Processing and fresh market aptitudes. Scientia Horticulturae. 140: 100-106.

ONUR, C., KASKA, N. (1985): Selection of pomegranate of Mediterranean region. Turkey Journal of Agriculture and Forestry. D2, 9.1: 25-33.

RADUNIĆ, M., JUKIĆ ŠPIKA, M., GORETA BAN, S., GADŽE J., DIAZ PEREZ, J.C., MACLEAN, D. (2015): Physical and chemical properties of pomegranate fruit accessions from Croatia. Food Chemistry. 177: 53-60.

RIBÉREAU-GAYON, P., STONESTREET, E. (1965): Determination of anthocyanins in red wine. Bulletin de la Societe Chimique de France. 9: 2649-2652.

SINGLETON V.L., ROSSI J.A. (1965): Jr: Colorimetry of total phenolics with phosphomolybdic-phosphotungstic acid reagents. American Journal of Enology and Viticultura. 16:144-158.

SCHWARTZ, E., TZULKER, R., GLAZER, I., BAR-YA'AKOV, I., WIESMAN, Z., TRIPLER, E., AMIR, R. (2009): Environmental conditions affect the color, taste, and antioxidant capacity of 11 pomegranate accessions' fruits. Journal of Agriculture and Food Chemistry. 57(19): 9197-9209.

StatSoft, Inc.USA (2012). Statistica software version 11.0 

activity introduced tje pomegranate (Punica granatum L.) cultivars grown in the

TEHRANIFAR, A., ZAREI, M., NEMATI, Z., ESFANDIYARI, B., VAZIFESHENAS, M. R. (2010): Investigation of physico-chemical properties and antioxidant activity of twenty Iranian pomegranate (Punica granatum L.) cultivars. Scientia Horticultura. 126: 180-185.

WETZSTEIN, H.Y., ZHANG, Z., RAVID, N., WETZSTEIN, M. E. (2011): Characterization of attributes related to fruit size in pomegranate. HortScience. 46(6): 908-912.

\section{Adresa autora - Author's address:}

Mira Radunić, e-mail: Mira.Radunic@krs.hr,

Katarina Lozo,

Ela Šimera,

Maja Jukić Špika

Institute for Adriatic Crops and Karst Reclamation,

Put Duilova 11, 21000 Split, Croatia

Jelena Gadže,

Faculty of Agriculture University of Zagreb,

Svetošimunska 25, 10000 Zagreb, Croatia 